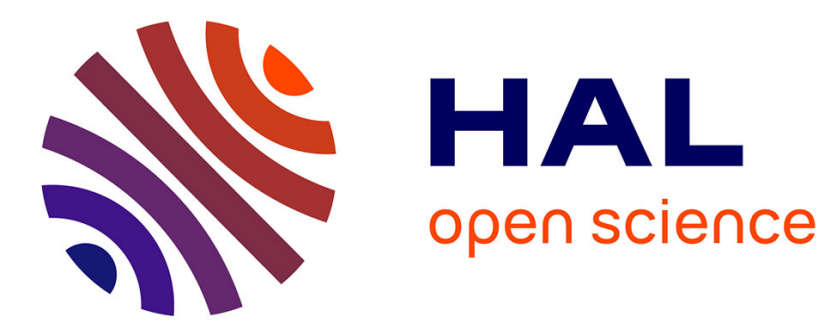

\title{
Optimisation of a whey protein fractionation process based on the selective precipitation of $\alpha$-lactalbumin
}

C Bramaud, P Aimar, G Daufin

\section{To cite this version:}

C Bramaud, P Aimar, G Daufin. Optimisation of a whey protein fractionation process based on the selective precipitation of $\alpha$-lactalbumin. Le Lait, 1997, 77 (3), pp.411-423. hal-00929535

\section{HAL Id: hal-00929535 https://hal.science/hal-00929535}

Submitted on 1 Jan 1997

HAL is a multi-disciplinary open access archive for the deposit and dissemination of scientific research documents, whether they are published or not. The documents may come from teaching and research institutions in France or abroad, or from public or private research centers.
L'archive ouverte pluridisciplinaire HAL, est destinée au dépôt et à la diffusion de documents scientifiques de niveau recherche, publiés ou non, émanant des établissements d'enseignement et de recherche français ou étrangers, des laboratoires publics ou privés. 


\title{
Optimisation of a whey protein fractionation process based on the selective precipitation of $\alpha$-lactalbumin
}

\author{
C Bramaud ${ }^{1}$, P Aimar ${ }^{2}$, G Daufin $^{1 *}$ \\ ${ }^{\prime}$ Laboratoire de Recherches de Technologie Laitière, INRA, 65, rue de Saint-Brieuc, \\ 35042 Rennes Cedex; ${ }^{2}$ Laboratoire de Génie Chimique, CNRS, Université Paul-Sabatier, \\ 118 , route de Narbonne, 31062 Toulouse Cedex, France
}

(Received 1 February 1996; accepted 10 January 1997)

\begin{abstract}
Summary - Whey protein fractionation based on the selective isoelectric precipitation of $\alpha$-lactalbumin has been optimised by an overall approach. Precipitation phenomena and rheological characteristics of the fluid after heat treatment have both been considered. Control of calcium concentration, a new operating parameter, has optimised the precipitation step. A reduction of this concentration leads to an increase in the $\alpha$-lactalbumin fraction precipitated at a moderate protein concentration. The use of citric acid, a calcium complexation agent, is proposed. It permits simultaneous adjustment of the $\mathrm{pH}$ and a reduction in the free calcium concentration. Co-precipitation of immunoglobulins and bovine serum albumin has been studied. However, there are no conditions under which $\alpha$-lactalbu$\mathrm{min}$ is the only protein that precipitates. To separate precipitated and soluble fractions, centrifugation is the method proposed, as it is more efficient than microfiltration. After solubilisation, the two forms of $\alpha$-lactalbumin may be recovered: the apo- $\alpha$-lactalbumin with a calcium-free solvent, and the native form with a calcium solvent. When a solution of calcium chloride is used, solubilisation is a fractionation step (increase of $23 \%$ in $\alpha$-LA purity), as the immunoglobulins remain insoluble.
\end{abstract}

whey protein / fractionation / optimisation / precipitation / solubilisation

Résumé - Optimisation d'un procédé de fractionnement des protéines du lactosérum fondé sur la précipitation sélective de l' $\alpha$-lactalbumine. Le procédé de fractionnement des protéines du lactosérum par précipitation isoélectrique de l' $\alpha$-lactalbumine est optimisé selon une approche globale. Les phénomènes de précipitation et les caractéristiques rhéologiques du fluide après traitement thermique sont pris en compte. Le contrôle de la concentration en calcium, paramètre opératoire additionnel, permet d'optimiser l'étape de précipitation, car lorsque cette teneur est réduite, le phénomène de précipitation de l' $\alpha$-lactalbumine est amplifié. L'utilisation d'acide citrique, agent de complexation du calcium, est la procédure proposée. Elle permet d'ajuster simultanément le pH et de réduire la concentration en calcium ionique. La coprécipitation des immunoglobulines et de la sérum albumine bovine dans la gamme de conditions opératoires étudiées est un phénomène inévitable.

* Correspondence and reprints 
La centrifugation, plus efficace que la microfiltration, est le moyen proposé pour séparer les phases soluble et précipitée. Selon la composition saline du solvant, l'étape de solubilisation permet de produire les deux formes de l' $\alpha$-lactalbumine. L'utilisation d'une solution de chlorure de calcium apporte une nouvelle sélectivité au procédé de fractionnement (gain de $23 \%$ de pureté en $\alpha$-LA), les immunoglobulines ne se solubilisant pas.

protéine du lactosérum / fractionnement / optimisation / précipitation / solubilisation

\section{INTRODUCTION}

Whey is a co-product of the dairy industry available in large amounts from cheese or casein manufacture. Global production is about 130 million tonnes of liquid per year. Whey contains lactose, proteins, salts and residual fat. Many processing technologies have been developed to use whey (Maubois et al, 1987; Zadow, 1992). Development of ultrafiltration to concentrate whey proteins has enabled the manufacture of whey protein concentrates (WPC) containing 35 to $75 \%$ protein. Residual fat in whey is detrimental to some functional properties of whey protein products, notably their foaming ability. From a processing standpoint, lipids and mineral salts are assumed to promote heavy fouling of ultrafiltration membranes and irreversibly contaminate ion exchange resins and membrane enzyme reactors. This residual fat may be removed by pre-treatment, ie, clarification.

The individual functional properties of whey proteins are less than optimal in WPC. Whey protein fractionation may allow the production of purified fractions which are potential sources of protein derivatives with a wide range of nutritional and therapeutic applications (Maubois and Léonil, 1989; Meisel et al, 1989). The main whey proteins are $\alpha$-lactalbumin ( $\alpha$-LA), $\beta$-lactoglobulin $(\beta-L G)$, bovine serum albumin (BSA) and immunoglobulins (Ig). Their fractionation may be performed by ion-exchange chromatography (Ayers and Petersen, 1985; Skudder, 1985), ion depletion at low $\mathrm{pH}$ (Amundson et al, 1982), addition of a precipitant (Al-Mashikh and Nakai, 1987) or heat separation (Pearce, 1983). Pearce studied the solubility of $\alpha$-LA and $\beta$-LG in aqueous solvent, as a function of temperature, $\mathrm{pH}$ and protein concentration. $\alpha$-LA and $\beta$-LG remained entirely soluble at all values of $\mathrm{pH}$ between 3.0 and 9.0 at temperatures up to $50^{\circ} \mathrm{C}$. At $55^{\circ} \mathrm{C}$, some turbidity in solutions of both proteins was observed. $\alpha$-LA showed a higher tendency to aggregate under certain conditions, $T>50^{\circ} \mathrm{C}$ and $4.2<\mathrm{pH}<4.6$, this range of $\mathrm{pH}$ corresponding to the isoelectric $\mathrm{pH}$ of $\alpha$-LA. The tendency to aggregate increased with concentration. The aggregates were partially resolubilised by readjustment of $\mathrm{pH}$ and temperature, Pearce (1983) ascribed the observed reduced solubility in the isoelectric zone to the presence of an intermediate denatured form (unfolded-like state) at 50 to $65^{\circ} \mathrm{C}$. The selective precipitation of $\alpha$-LA is the basis of a process for the production of fractions enriched in $\alpha$-LA and $\beta$-LG. Scaling up to pilot-scale has been reported by Pierre and Fauquant (1986) and by Pearce (1987). They used a different raw material for a similar whey protein fractionation. Pearce fractionated proteins from a raw WPC, whereas Pierre and Fauquant used a defatted WPC in order to recover protein fractions with better functional properties. After a clarification step according to the method described by Fauquant et al (1985), the defatted whey was concentrated about 30 -fold by ultrafiltration prior to $\mathrm{pH}$ adjustment at 3.8 and heat treatment at $55^{\circ} \mathrm{C}$ for $30 \mathrm{~min}$. Before separation of the precipitated and soluble phases by centrifugation, dilution by a factor of 2 was necessary owing to the gel texture of the fluid. 
Recent improvements in the pre-treatment of whey and in the knowledge of the $\alpha$-LA solubility mechanism led to a reexamination of this fractionation process. $\alpha$-LA is a calcium metalloprotein (Hiraoka et al, 1980). We recently showed the specificity of the isoelectric precipitation of $\alpha$-LA, owing to the calcium ion that is strongly bound to the $\alpha$-LA (Bramaud et al, 1995a). $\alpha$-LA can exist in the native or in the calcium-free form (apo form), the latter being more hydrophobic than the native form. It is characterised by poor solubility and precipitates at an isoelectric $\mathrm{pH}$. At this $\mathrm{pH}$, increased temperature and a decrease in the calcium-free concentration favour the formation of the calcium-free form of the protein, resulting in a greater extent of $\alpha$ LA precipitation. Selective precipitation, separation of the liquid from the solid phase and dissolution have been considered together with the interaction between such operations. Because of the gelation properties of WPC at acidic $\mathrm{pH}$, we suggest that precipitation be carried out at a lower protein concentration than in the procedure reported by Pierre and Fauquant (1986). The precipitation step may be optimised by considering calcium concentration as an operating parameter. In fact, reduction in calcium-free concentration permits a higher degree of precipitated fractions to be obtained. The behaviour of the major whey proteins ( $\beta$-LG, BSA, Ig and caseinomacropeptide: CMP) has been studied under the physicochemical conditions of $\alpha$-LA precipitation to assess the extent of the co-precipitation phenomena and to determine whether there are conditions under which $\alpha$-LA is the only protein that precipitates.

\section{MATERIALS AND METHODS}

\section{Solutions}

Rennet whey protein concentrate (liquid WPC), preconcentrated five times by ultrafiltration, was purchased from Eurial (Herbignac, France). Concentrations of the WPC were: $C_{\alpha-L A}=3.6 \mathrm{~g} \mathrm{~L}^{-1}$, $C_{\beta-\mathrm{LG}}=10.7 \mathrm{~g} \mathrm{~L}^{-1}, C_{\mathrm{BSA}}=1.0 \mathrm{~g} \mathrm{~L}^{-1}$, $C_{\mathrm{Ig}}^{\beta-\mathrm{LG}}=3.0 \mathrm{~g} \mathrm{~L}^{-1}, C_{\mathrm{CMP}}=5.2 \mathrm{~g} \mathrm{~L}^{-1}$. The defatting procedure for this WPC (Fauquant et al, 1985) was as follows: clarification took place with a pre-treatment of aggregation of phospholipids and phospholipoproteins ( $\mathrm{pH}$ adjusted to 7.5 at $2{ }^{\circ} \mathrm{C}$, temperature adjusted to $55^{\circ} \mathrm{C}$, heat-treatment at $55^{\circ} \mathrm{C}$ for $15 \mathrm{~min}$ ) followed by microfiltration ( $0.1 \mu \mathrm{m}$ membrane, SCT, Bazet, France). Protein concentrations in the defatted WPC were: $C_{\alpha-\mathrm{LA}}=2.3 \mathrm{~g} \mathrm{~L}^{-1}, C_{\beta-\mathrm{LG}}=9.25 \mathrm{~g} \mathrm{~L}^{-1}$, $C_{\mathrm{BSA}}^{\alpha-\mathrm{LA}}=0.6 \mathrm{~g} \mathrm{~L}^{-1}, C_{\mathrm{lg}}=1.5 \mathrm{~g} \mathrm{~L}^{-1}$, $C_{\mathrm{CMP}}=4.8 \mathrm{~g} \mathrm{~L}^{-1}$. The calcium and sodium content were: 0.21 and $0.48 \mathrm{~g} \mathrm{~L}^{-1}$. Protein concentration was adjusted by ultrafiltration with an AMICON S10Y3 membrane (Amicon, Uppermill, UK), with a molecular weight cut-off of $3 \mathrm{kDa}$.

\section{Operating procedure}

$\mathrm{pH}$ was adjusted in the range $2.0-8.0$ with $5 \mathrm{~N}$ $\mathrm{HCl}, 2 \mathrm{~N}$ citric acid, and $2 \mathrm{~N} \mathrm{NaOH}$. The freecalcium concentration was adjusted with sodium citrate and citric acid. Heat treatment was performed in centrifuge tubes capped and immersed in a water-bath at the required temperature (20 to $65^{\circ} \mathrm{C}$ ) for a given time. Separation of the precipitated and soluble phases (Bramaud et al, $1995 \mathrm{~b})$ was performed by centrifugation $(4000 \mathrm{~g}$, $\left.30 \mathrm{~min}, 20^{\circ} \mathrm{C}\right)$ or by diafiltration $(0.5 \mu \mathrm{m}$ membrane, SCT, Bazet, France). Samples of supernatant were removed for protein estimation. Protein content ( $\alpha$-LA, $\beta$-LG, BSA and IgG) was determined by reverse-phase chromatography with a PLRP-S column and an acetonitrile gradient at $\mathrm{pH} 2.0$. Proteins were detected at $210 \mathrm{~nm}$. Ion concentrations of $\mathrm{Ca}^{2+}, \mathrm{Mg}^{2+}, \mathrm{Na}^{+}$and $\mathrm{K}^{+}$ were determined by atomic absorption (Varian spectra AA 300, Springvale, Australia) as described by Brulé et al (1974).

The precipitation was characterised by the precipitated fraction, $X$, of each protein and by the texture of the sediment after centrifugation, determined as follows. For a given time of heat-treatment, the amount of precipitated protein was determined as the amount removed from the soluble phase (supernatant), divided by the initial protein concentration:

$$
X=\frac{C_{\mathrm{T}}-C_{\text {sup }}}{C_{\mathrm{T}}}=1-\frac{C_{\text {sup }}}{C_{\mathrm{T}}}
$$


where $C_{\mathrm{T}}$ is the initial protein concentration and $C_{\text {sup }}$ its concentration in the supernatant. When the precipitation reaction was at steady state, the precipitated fraction was noted as $X_{f}$. The texture of the sediment after heat-treatment was characterised by the weight fraction of the sediment:

$$
F_{\mathrm{w}}=\frac{w_{\mathrm{s}}}{w_{\mathrm{t}}}
$$

where $w_{\mathrm{s}}$ and $w_{\mathrm{t}}$ are the weight of the sediment and of the initial sample, respectively. The more water entrapped in the sediment, the higher the value of $w_{\mathrm{s}}$. Accordingly, for an $F_{\mathrm{W}}$ equal to 1.0, all the sample would have been gelified, whereas if $F_{W}$ was close to zero, the sediment would be low in water. As the sediment held water and entrapped $\beta$-LG, the pellets were washed: dispersion in a $\mathrm{NaCl}\left(0.1 \mathrm{~mol} \mathrm{~L}^{-1}\right)$ solution at $\mathrm{pH}$ 3.9 , centrifugation $\left(4000 \mathrm{~g}, 30 \mathrm{~min}, 20^{\circ} \mathrm{C}\right)$. After dispersion of the sediment in an aqueous solution at $20{ }^{\circ} \mathrm{C}\left(\mathrm{NaCl}\right.$ or $\mathrm{CaCl}_{2}$, ionic strength $0.1 \mathrm{~mol} \mathrm{~L}^{-1}$ ), the $\mathrm{pH}$ was adjusted in the range 2.0-8.0 and the insoluble part was removed by centrifugation $\left(4000 \mathrm{~g}, 20^{\circ} \mathrm{C}, 30 \mathrm{~min}\right)$.

Each step in the fractionation process was characterised by the yield, $\eta$, and by the purity, $P$, of each protein ( $\alpha$-LA, $\beta$-LG, BSA, Ig).

\section{RESULTS AND DISCUSSION}

\section{Operating conditions during the precipitation and purification steps}

\section{Co-precipitation of $\alpha-L A, B S A$ and Ig}

In a defatted whey protein concentrate, the $\mathrm{pH}$ of maximal precipitation of BSA and $\mathrm{Ig}$, which is $\sim 4.0$, is equal to that of $\alpha-\mathrm{LA}$ (fig 1). The maximal precipitated fraction of $\beta$-LG is $\sim 0.02$. The ionic strength of a defatted WPC is $\sim 0.1 \mathrm{~mol} \mathrm{~L}^{-1}$. Figure 2 shows the influence of temperature on the precipitated fractions of $\alpha-\mathrm{LA}, \mathrm{BSA}$ and Ig at $\mathrm{pH}$ 3.9. At temperatures above $60^{\circ} \mathrm{C}$, the precipitation of $\mathrm{BSA}$ is total. The instability of BSA at acidic $\mathrm{pH}$, characterised by a conformational change in the $\mathrm{pH}$ range 3.6 to 4.0 , has been well established (Tanford et

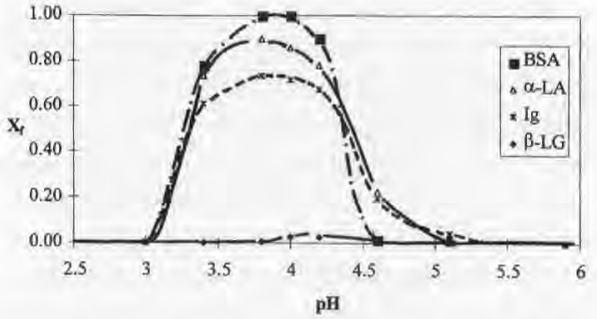

Fig 1. Precipitated fraction, $X_{\mathrm{f}}$, of $\alpha$-LA, $\beta$-LG, BSA, Ig versus $\mathrm{pH}$. Heat treatment $\left(T=60^{\circ} \mathrm{C}\right.$, $150 \mathrm{~min}) ; C_{\alpha-\mathrm{LA}}=4.1 \mathrm{~g} \mathrm{~L}^{-1}, C_{\beta-\mathrm{LG}}=23.5 \mathrm{~g} \mathrm{~L}^{-1}$, $C_{\mathrm{BSA}}=1.2 \mathrm{~g} \mathrm{~L}^{-1} \cdot C_{\mathrm{Ig}}=3.8 \mathrm{~g} \mathrm{~L}^{-1}$.

Taux de précipitation, $\mathrm{X}_{f}$ de l' $\alpha-L A$, de la $\beta-L G$, de la BSA et des Ig en fonction du $\mathrm{pH}$. Traitement thermique à $60^{\circ} \mathrm{C}$ pendant $150 \mathrm{~min}$.

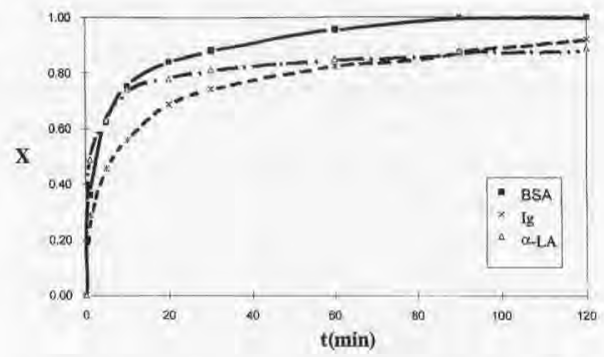

Fig 2. Precipitated fraction, $X_{f}$, of $\alpha-\mathrm{LA}$, BSA, Ig versus temperature $T$. Duration: $150 \mathrm{~min}$, $\mathrm{pH} 3.9 ; C_{\alpha-\mathrm{LA}}=2.5 \mathrm{~g} \mathrm{~L}^{-1}, C_{\mathrm{BSA}}=0.6 \mathrm{~g} \mathrm{~L}^{-1}$, $C_{\mathrm{Ig}}=1.5 \mathrm{~g} \mathrm{~L}^{-1}$.

Taux de précipitation, $\mathrm{X}_{p}$ de l' $\alpha-L A$, de la $\beta-L G$, de la BSA et des Ig en fonction de la température. Traitement thermique pendant $150 \mathrm{~min}$, pH 3,9.

al, 1955; Svenson et Carlsson, 1975). Lin and Koenig (1976) observed a partial unfolding of the protein in the temperature range $42-50{ }^{\circ} \mathrm{C}$ resulting in its total insolubilisation. Co-precipitation of Ig has already been observed by Pearce (1987). However, a study of this phenomenon has not to our knowledge been reported. Ig has a higher denaturation temperature (characterised by the unfolding of the protein) than $\alpha$-LA and B-LG (de Wit, 1989; Morr and Ha, 1993). In 


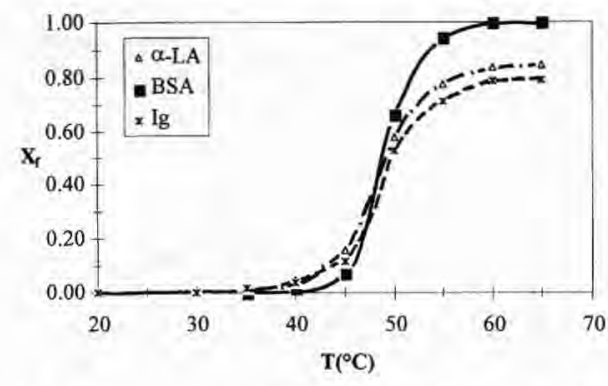

Fig 3. Precipitation kinetics of $\alpha-\mathrm{LA}, \mathrm{BSA}$ and $\mathrm{Ig}$ at $T=60^{\circ} \mathrm{C}, \mathrm{pH}=3.9 ; C_{\alpha-\mathrm{LA}}=2.5 \mathrm{~g} \mathrm{~L}^{-1}$, $C_{\mathrm{BSA}}=0.6 \mathrm{~g} \mathrm{~L}^{-1}, C_{\mathrm{Ig}}=1.5 \mathrm{~g} \mathrm{~L}^{-1}$.

whey, the presence of the other proteins renders Ig heat-sensitive. As $\beta$-LG remains soluble, precipitation of Ig does not result from interactions with this protein. It may result from interactions with BSA and with apo- $\alpha$ $\mathrm{LA}$, as this form of the protein is more hydrophobic than the native form. Precipitation kinetics of $\alpha$-LA, BSA and Ig are similar, as shown in figure 3 . The order of the $\alpha$ LA precipitation reaction cannot be determined, as this protein is in two different forms (native and calcium-free forms) and as these two concentrations were not determined experimentally. The precipitation reactions of BSA and Ig are of second order.

\section{Influence of protein concentration on the sediment texture}

Even if more than $98 \%$ of the $\beta$-LG remains soluble, its presence is problematic at a high protein concentration, as gelation properties of WPC at $\mathrm{pH}$ values lower than 4.5 and at temperatures above $50^{\circ} \mathrm{C}$ are essentially due to this protein (Gault and Fauquant, 1992). The texture of the sediment and the efficiency of the separation of soluble and precipitated phases differ according to the total solid concentration.
When the total concentration in proteins, $C_{\text {WPC }}$, increases, gelation results in an increase in the weight fraction of the sediment, $F_{\mathrm{W}}$. For instance, we consider $\alpha$-LA as representative of the precipitated proteins and $\beta$-LG of the soluble proteins. The weight fraction of $\alpha-\mathrm{LA} \frac{q_{\alpha-\mathrm{LA}}}{q_{\alpha-\mathrm{LA}}+q_{\beta-\mathrm{LG}}}$ in the precipitated phase of the sediment depends on the texture of fluids and on the extent of $\alpha$-LA precipitation.

For a WPC such as $C_{\beta-\mathrm{LG}}=5 C_{\alpha-\mathrm{LA}}$, the weight fraction in $\alpha$-LA is 0.17 . Assuming that $\beta$-LG remains entirely soluble, the weight fraction in $\alpha$-LA in the sediment after precipitation and separation by centrifugation is estimated by $F_{\alpha-\mathrm{LA}}$ :

$$
\begin{aligned}
F_{\alpha \mathrm{LA}} & =\left(\frac{q_{\alpha-\mathrm{LA}}}{q_{\alpha-\mathrm{LA}}+q_{\beta}-\mathrm{LG}}\right)_{\text {prec }} \\
& =\frac{F_{\mathrm{W}}\left(1-X_{\mathrm{f}}\right)+X_{\mathrm{f}}}{F_{\mathrm{W}}\left(1-X_{\mathrm{f}}\right)+X_{\mathrm{f}}+5 F_{\mathrm{W}}}
\end{aligned}
$$

where $X_{\mathrm{f}}$ and $F_{\mathrm{W}}$ are the precipitated fraction in $\alpha$-LA and the weight fraction of the sediment.

Figure 4 shows the effect of $F_{\mathrm{W}}$ on $F_{\alpha-\mathrm{LA}}$ (eq 3). For a given precipitated fraction, $X_{f}$, the weight fraction in $\alpha$-LA decreases when $F_{\mathrm{W}}$ increases. Even if $\beta$-LG does not precipitate, an increasing proportion of this protein (fraction equal to the weight fraction of the sediment) is entrapped in the sediment. It results in a less efficient separation of precipitate and soluble proteins. As the increase in total protein concentration induces both the increase in the precipitated fraction and in the weight fraction of the sediment, it results in a lower $\alpha$-LA purity in the precipitated phase. For instance, when the $\alpha$-LA concentration in the WPC increased from 2.5 to $15 \mathrm{~g} \mathrm{~L}^{-1}$, the precipitated fraction increased from 0.6 to 0.9 and 


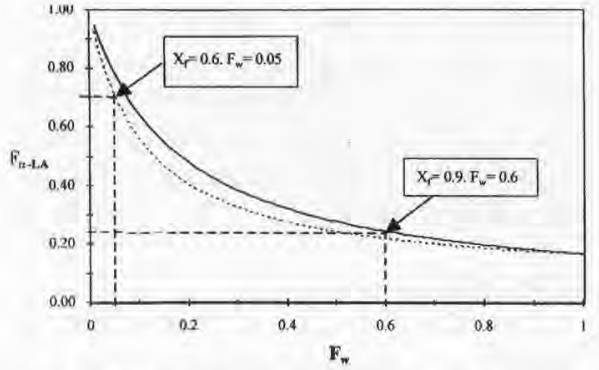

Fig 4. Weight fraction in $\alpha-L A$ in the precipitated fraction, $F_{\alpha-\mathrm{LA}}$, after precipitation and separation by centrifugation versus the weight fraction of the sediment, $F_{\mathrm{W}}$, for two values of the $\alpha$-LA precipitated fraction, $X_{\mathrm{f}^{*}}-, X_{\mathrm{f}}=0.9$; $\ldots, X_{\mathrm{f}}=0.6$.

Fraction massique de l' $\alpha$-LA dans la phase précipitée, $\mathrm{F}_{\alpha-L A}$, après l'étape de précipitation et la séparation par centrifugation en fonction de la fraction massique du sédiment, $\mathrm{F}_{w}$, pour deux taux de précipitation de l' $\alpha-L A, \mathrm{X}_{f}$

the weight fraction of the sediment increased from 0.05 to 0.6 . It resulted in an $\alpha$-LA purity of 0.22 instead of 0.7 . When the protein concentration is increased by ultrafiltration, the ionic strength in the WPC is almost constant. Thus, optimisation of the precipitation step through the increase in the total protein concentration induces a less efficient separation between the precipitated and soluble phases, as the increase in the sediment fraction leads to a lower enrichment in $\alpha$-LA.

\section{Optimisation of $\alpha-L A$ precipitation at a moderate protein concentration}

As a decrease in the calcium-free concentration (Bramaud et al, 1995a) has been shown to have a positive influence, a series of experiments was conducted in which citrate (a calcium complexation agent) was added. Figure 5 shows the effect of citrate addition $\left(4010^{-3}\right.$ and $\left.9610^{-3} \mathrm{~mol} \mathrm{~L}^{-1}\right)$ on the precipitation phenomenon of $\alpha-\mathrm{LA}$ at $\mathrm{pH} 3.9$ in the temperature range $20-65^{\circ} \mathrm{C}$. When the $\mathrm{pH}$ is adjusted with citric acid, the amount of added citrate is

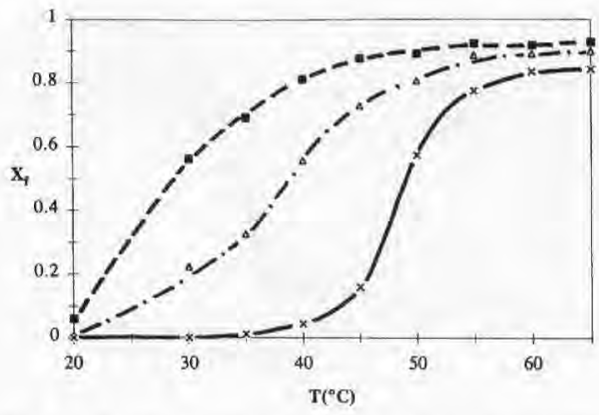

Fig 5. Precipitated fraction of $\alpha$-LA, $X$, versus temperature, $T$, for different citrate content. Duration: $150 \mathrm{~min}, \mathrm{pH} 3.9 . C_{\alpha-\mathrm{LA}}=2.5 \mathrm{~g} \mathrm{~L}^{-1}$; (四) $9610^{-3} \mathrm{~mol} \mathrm{~L}^{-1} ;(\triangle) 4010^{-3} \mathrm{~mol} \mathrm{~L}^{-1}$; (X) $010^{-3} \mathrm{~mol} \mathrm{~L}^{-1}$.

Taux de précipitation de l' $\alpha-L A, \mathrm{X}$, en fonction de la température, $\mathrm{T}$, pour différentes quantités de citrate. Traitement thermique pendant $150 \mathrm{~min}$

$4010^{-3} \mathrm{~mol} \mathrm{~L}^{-1}$. The most important increase in the precipitated fraction is observed at temperatures below $50{ }^{\circ} \mathrm{C}$. For instance, the $\alpha$-LA precipitated fraction at $35^{\circ} \mathrm{C}$ is 0.7 , when $9610^{-3} \mathrm{~mol} \mathrm{~L}^{-1}$ of citrate is added. No precipitation is observed when no citrate is used. The precipitation phenomenon at low temperature for a lower calcium concentration was predicted by the model developed by Bramaud et al (1995a). When citrate is added, the precipitation yield for a given protein concentration is almost independent of temperature in the range $50-65^{\circ} \mathrm{C}$.

\section{Optimisation of the separation of soluble and precipitated proteins}

Microfiltration and centrifugation are processes that allow precipitated and soluble phases to be separated. Microfiltration has been studied as an alternative separation method to centrifugation. It is less efficient than centrifugation, as higher solvent volumes are necessary (Bramaud et al, 1995b). 
As the sediment holds water, the remaining $\beta$-LG is removed by washing. To prevent $\alpha$-LA loss due to partial solubilisation, a $\mathrm{NaCl}$ solution $\left(0.1 \mathrm{~mol} \mathrm{~L}^{-1}\right)$ at $\mathrm{pH} 3.9$ was used (fig 6). At moderate protein concentration, two washing steps were necessary to remove $98 \%$ of the initial protein (table I).

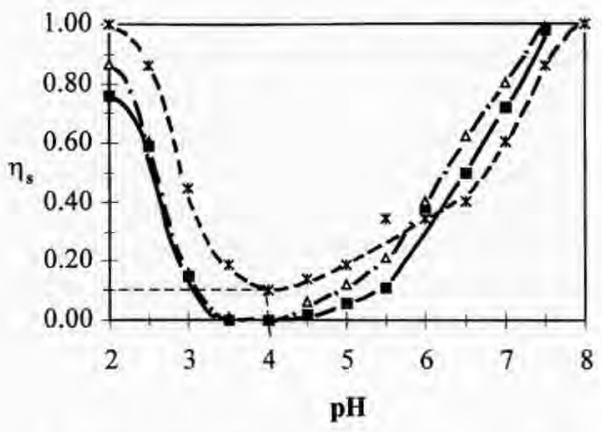

Fig 6. Solubilisation yield, $\eta_{s}$, of $\alpha$-LA, BSA and $\mathrm{Ig}$ versus $\mathrm{pH}$. Solubilisation solvent: $\mathrm{NaCl}$, $0.1 \mathrm{~mol} \mathrm{~L}^{-1} ;(\triangle) \alpha-\mathrm{LA} ;(\mathbf{\square}) \mathrm{BSA} ;(*) \mathrm{Ig}$. Rendement de solubilisation de l' $\alpha-L A$, de la $S A B$ et des Ig en fonction du $\mathrm{pH}$. Solvant de solubilisation : $\mathrm{NaCl}, 0,1 \mathrm{~mol} \mathrm{~L}^{-1}$.

Table I. Weight fraction for $\alpha-\mathrm{LA}, \frac{q_{\alpha-\mathrm{LA}}}{q_{\alpha-L \mathrm{~A}}+q_{\beta-\mathrm{LG}}}$ of the precipitated phase versus the number of washing steps by centrifugation.

Fraction massique de l' $\alpha-L A, \frac{\mathrm{q}_{\alpha-L A}}{\mathrm{q}_{\alpha-L A}+\mathrm{q}_{\beta-L G}}$ dans la phase précipitée en fonction du nombre de lavages par centrifugation.

\begin{tabular}{lcc}
\hline & $\frac{q_{\alpha L A}}{2}$ & $\begin{array}{c}\% \beta-L G \\
\text { eliminated }\end{array}$ \\
\hline WPC & 0.15 & - \\
1st CF & 0.42 & 90 \\
1st washing & 0.72 & 95 \\
2nd washing & 0.90 & 98 \\
3rd washing & 0.91 & 98 \\
\hline
\end{tabular}

WPC : whey protein concentrates.

\section{Solubilisation of precipitated proteins}

Solutions containing two forms of $\alpha$-LA, dependent on the mode of dispersion (salt composition of the solvent), could be recovered after solubilisation: apo- $\alpha$-LA and $\alpha$ $\mathrm{LA}-\mathrm{Ca}^{2+}$. After dispersion of the sediment in the solvent $\left(\mathrm{pH} 3.9,20^{\circ} \mathrm{C}\right.$, ionic strength $\left.0.1 \mathrm{~mol} \mathrm{~L}^{-1}\right)$, total protein concentrations were: $C_{\alpha-\mathrm{LA}}=1.8 \mathrm{~g} \mathrm{~L}^{-1}, C_{\beta-\mathrm{LG}}=0.2 \mathrm{~g} \mathrm{~L}^{-1}$, $C_{\mathrm{BSA}}=0.55 \mathrm{~g} \mathrm{~L}^{-1}, C_{\mathrm{Ig}}=1.1 \mathrm{~g} \mathrm{~L}^{-1}$.

\section{Apo- $\alpha-L A$ with calcium-free solvent}

Figure 6 illustrates the effect of $\mathrm{pH}$ in the range 2.0-8.0 on the extent of solubilisation of precipitated proteins in a $\mathrm{NaCl}$ solvent. After dispersion of the precipitates in a $\mathrm{NaCl}$ solution at $\mathrm{pH} 3.9\left(0.1 \mathrm{~mol} \mathrm{~L}^{-1}\right)$, the fluid is turbid, white and opaque. At $\mathrm{pH}$ $3.5-4.0, \alpha-\mathrm{LA}$ and BSA remain insoluble. Around $10 \%$ of Ig is solubilised. When the $\mathrm{pH}$ is higher than 7.5 , the initially turbid solution is clear and proteins are totally solubilised. When the $\mathrm{pH}$ is very different from the isoelectric $\mathrm{pH}$, proteins are solubilised, as electrostatic forces (protein-protein) are repulsive. At $\mathrm{pH} 8.0$, precipitated proteins are totally solubilised. $\alpha$-LA purity is $\sim 0.49$ owing to BSA, Ig and $\beta-\mathrm{LG}$, the purities of which are: $0.13,0.30$ and 0.08 , respectively. At $\mathrm{pH} 8.0$, dispersion in a $\mathrm{NaCl}$ solution permits the solubilisation of precipitated proteins with a protein yield of $\sim 1.0$. The composition of the soluble phase was: $C_{\alpha-\mathrm{LA}}=1.81 \mathrm{~g} \mathrm{~L}^{-1}, C_{\beta-\mathrm{LG}}=0.2 \mathrm{~g} \mathrm{~L}^{-1}$, $C_{\mathrm{BSA}}^{\alpha-\mathrm{LA}}=0.55 \mathrm{~g} \mathrm{~L}^{-1}, C_{\mathrm{Ig}}=1.1 \mathrm{~g} \mathrm{~L}^{-1}$.

\section{Solvent with calcium: $\alpha-L A-C a^{2+}$}

Figures 7 and 8 illustrate the effect of $\mathrm{pH}$ on the solubilisation yield of precipitated proteins in a $\mathrm{CaCl}_{2}$ solution (ionic strength, $0.1 \mathrm{~mol} \mathrm{~L}^{-1}$ ) and on protein purity in the soluble phase. After dispersion at pH 3.9, the fluid is turbid, white and opaque. In the $\mathrm{pH}$ range $2.5-8.0$, solutions remain turbid. Even at $\mathrm{pH} 8.0$, a fraction of precipitated 


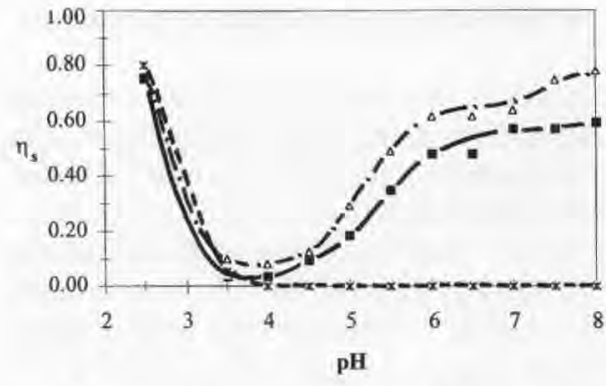

Fig 7. Solubilisation yield, $\eta_{\mathrm{s}}$, of $\alpha$-LA, BSA and $\mathrm{Ig}$ versus $\mathrm{pH}$. Solubilisation solvent: $\mathrm{CaCl}_{2}$, ionic strength $0.1 \mathrm{~mol} \mathrm{~L}^{-1} ; \triangle(\triangle) \alpha$-LA; $(\mathbf{D}) \mathrm{BSA}^{2}$; (*) Ig.

Rendement de solubilisation de l' $\alpha-L A$, de la $S A B$ et des Ig en fonction du $\mathrm{pH}$. Solvant de solubilisation: $\mathrm{CaCl}_{2}$, force ionique $0,1 \mathrm{~mol} \mathrm{~L}{ }^{-1}$.

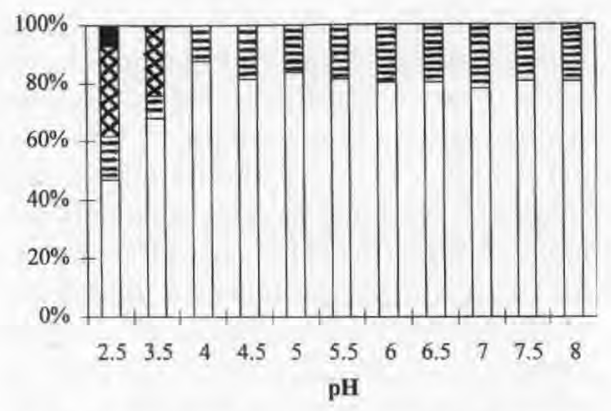

Fig 8. Composition of the solubilised fraction (weight\% of each protein) versus $\mathrm{pH}$. Solubilisation solvent: $\mathrm{CaCl}_{2}$, ionic strength $0.1 \mathrm{~mol} \mathrm{~L}^{-1}$; (囬) $\beta$-LA; (凶) Ig; (百) BSA; $\square$ ( $\alpha$-LA. Composition de la fraction soluble (\% massique de chaque protéine) en fonction du $\mathrm{pH}$. Solvant de solubilisation: $\mathrm{CaCl}_{2}$, force ionique $0,1 \mathrm{~mol} \mathrm{~L} L^{-1}$.

proteins remains insoluble. In the $\mathrm{pH}$ range $3.5-4.0,10$ and $4 \%$ of $\alpha-\mathrm{LA}$ and BSA are solubilised. At $\mathrm{pH} 8.0$, only 80 and $60 \%$ of these two proteins are solubilised, respectively. $\mathrm{Ig}$ remains insoluble in the $\mathrm{pH}$ range 4.0-8.0, whereas it is solubilised at acidic $\mathrm{pH}(\mathrm{pH}<4.0)$. There is no trace of $\beta$-LG in the soluble phase in the $\mathrm{pH}$ range 3.0-8.0. Because of the absence of $\mathrm{Ig}$ and $\beta$-LG, $\alpha$-LA purity is $\sim 0.80$ in the $\mathrm{pH}$ range
4.5-8.0. At $\mathrm{pH} 8.0$, the $\alpha$-LA solubilisation yield is 0.80 . The composition of the soluble phase is: $C_{\alpha-\mathrm{LA}}=1.44 \mathrm{~g} \mathrm{~L}^{-1}$, $C_{\mathrm{BSA}}=0.45 \mathrm{~g} \mathrm{~L}^{-1}$.

Control of the salt nature of the solubilisation solvent (ionic strength $0.1 \mathrm{~mol} \mathrm{~L}^{-1}$ ) allows selective solubilisation of $\mathrm{Ig}$. The presence of $\beta$-LG in the soluble phase is probably linked to that of $\mathrm{Ig}$. In the $\mathrm{CaCl}_{2}$ solvent and in the $\mathrm{pH}$ range $4.0-8.0, \mathrm{Ig}$ remain insoluble and there is no $\beta-\mathrm{LG}$ in the soluble phase. In this solvent at $\mathrm{pH} 2.5$, and in the $\mathrm{NaCl}$ solvent in the whole $\mathrm{pH}$ range, both Ig and $\beta$-LG are present in the soluble phase. In the $\mathrm{CaCl}_{2}$ solvent at $\mathrm{pH}$ 8.0 , the lower solubilisation yields of $\alpha$-LA and BSA ( 0.80 and 0.60$)$ may be ascribed to hydrophobic interactions with Igs, as these proteins remain insoluble. However, using this solvent allows an increase of $23 \%$ in purity of $\alpha$ - LA. As Ig is totally soluble in a $\mathrm{NaCl}$ solution, its irreversible insolubilisation in the $\mathrm{CaCl}_{2}$ solution is due to physicochemical characteristics and to the specific influence of calcium.

In the $\mathrm{NaCl}$ solution at $\mathrm{pH} 3.9, \alpha-\mathrm{LA}$ precipitation is irreversible. This irreversibility is used to reduce $\alpha$-LA loss during the washing step for precipitated proteins. The presence of calcium leads to slight solubility. In fact, the $\mathrm{Ca}^{2+}$-protein complexation equilibrium is displaced, which favours the formation of the most soluble form of the protein at $\mathrm{pH} 4.0$ (calcium- $\alpha$-LA) .

Pearce (1988) reported a maximum $\alpha$ LA solubilisation yield of 0.80 in the $\mathrm{pH}$ range 6.5-8.0. We obtained higher solubilisation yields in a $\mathrm{NaCl}$ solution. Pierre and Fauquant (1986) performed a clarification step at the end of the purification process to remove residual lipoproteins. They adjusted the $\mathrm{pH}$ to 7.0 , added $1.2 \mathrm{~g} \mathrm{~L}^{-1}$ of calcium $\left(0.03 \mathrm{M}\right.$ of $\left.\mathrm{CaCl}_{2}\right)$ and maintained the temperature at $55^{\circ} \mathrm{C}$ for $10 \mathrm{~min}$. The result of this step was similar to our re-solubilisation experiments with $\mathrm{CaCl}_{2}$ at $20^{\circ} \mathrm{C}$. Higher $\alpha$-LA purities obtained by the pro- 
cedure of Pierre and Fauquant are probably due to the presence of calcium, which prevents Ig re-solubilisation.

\section{Fractionation process}

\section{Operating conditions for each step}

The defatting procedure for the WPC removes phospholipids and reduces the calcium concentration by a factor of 2 (from 0.4 to $0.2 \mathrm{~g} \mathrm{~L}^{-1}$ ). This lower calcium concentration favours higher $\alpha$-LA precipitated fractions during the precipitation process. Gelation affects separation of the precipitated phase from the soluble phase. It is necessary to limit the total concentration of proteins in the process. As the presence of citrate allows high precipitation levels at moderate concentrations of $\alpha$-LA, we concluded that this defatted WPC could be used without a further concentration step. Therefore, ultrafiltration, which is currently performed to adjust protein concentration, is no longer necessary and the precipitation step can be made directly.

For temperatures of $\sim 50{ }^{\circ} \mathrm{C}$, often used in the dairy industry to improve transfer velocities while preserving most of the functional properties of proteins, the quantity of citrate added when the $\mathrm{pH}$ is adjusted to 3.9 with citric acid (40 $10^{-3} \mathrm{~mol} \mathrm{~L}^{-1}$ citrate) is sufficient to obtain the greatest precipitated fraction (fig 5). In this case, a temperature of $55^{\circ} \mathrm{C}$ is chosen for the precipitation step, as the $\alpha$-LA precipitated fraction remains the same at higher temperatures (fig 9). At this temperature, the optimal duration of heat-treatment is $30 \mathrm{~min}$ (fig 10). The $\alpha$ LA precipitated fraction is $\sim 0.81$. For a longer duration, the increase in precipitated fraction would be very small. A supplementary heat-treatment of $30 \mathrm{~min}$ induces an increase of only 0.04 in the precipitated fraction.

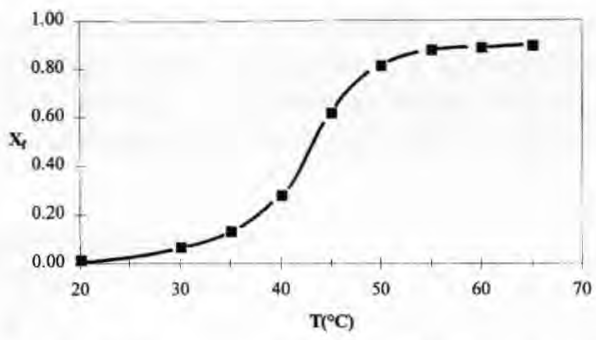

Fig 9. $\alpha$-LA precipitated fraction, $X_{\mathrm{f}}$, versus temperature, $T$. Heat treatment: $150 \mathrm{~min}, \mathrm{pH} 3.9$; $C_{\alpha-\mathrm{LA}, \mathrm{T}}=2.5 \mathrm{~g} \mathrm{~L}^{-1}$. Acidification with citric acid $(2 \mathrm{~N})$.

Taux de précipitation de l' $\alpha-L A, \mathrm{X}_{f}$ en fonction de la température, T. Traitement thermique: 150 min à $p H 3,9 . C_{\alpha \cdot L A, T}=2,5 \mathrm{~g} \mathrm{~L}^{-1}$. Acidification avec l'acide citrique ( $2 \mathrm{~N}$ ).

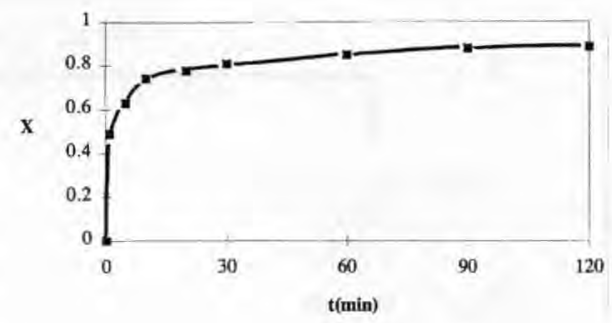

Fig 10. Kinetics of $\alpha$-LA precipitation at $55^{\circ} \mathrm{C}$. Acidification with citric acid $(2 \mathrm{~N}) . \mathrm{pH} 3.9$. $C_{\alpha-\mathrm{LA}, \mathrm{T}}=2.5 \mathrm{~g} \mathrm{~L}^{-1}$.

Cinétique de précipitation de l' $\alpha$-LA à $55^{\circ} \mathrm{C}$. pH ajusté avec l'acide citrique (2 N). pH 3,9.

After precipitation and separation by centrifugation, two washing steps with a $\mathrm{NaCl}$ solution at $\mathrm{pH} 3.9\left(0.1 \mathrm{~mol} \mathrm{~L}^{-1}\right)$ are necessary to remove $98 \%$ of the initial $\beta-\mathrm{LG}$. The soluble fraction ( $\beta$-LG) contains CMP, lactose and minerals. It may be purified by diafiltration at an acidic $\mathrm{pH}$, as CMP are monomers (Tanimoto et al, 1990).

After washing in the precipitated phase, operating conditions (salt composition of the solvent) during solubilisation depend on the further use of proteins and on purity requirements. When this fraction is intended for the food industry, the additional cost involved in achieving higher purity is not 
necessary. The use of a $\mathrm{NaCl}$ solution $\left(0.1 \mathrm{~mol} \mathrm{~L}^{-1}\right)$ is interesting, as the recovery yield of soluble proteins is 1.0. The purity in $\alpha-\mathrm{LA}$ is 0.56 . The main contaminants are
BSA and Ig. For higher purity requirements in $\alpha$-LA, the use of a $\mathrm{CaCl}_{2}$ solution (ionic strength $0.1 \mathrm{~mol} \mathrm{~L}^{-1}$ ) results in an increase of $23 \%$ in $\alpha$-LA purity. The recovery yield

\section{Defatted Whey Protein Concentrate}

FRV 5

$\downarrow$

$\mathrm{pH}$ adjustment with citric acid

HEAT-TREATMENT

(pH $3.9,55^{\circ} \mathrm{C}, 30 \mathrm{~min}$ )

CENTRIFUGATION

$\left(4000 \mathrm{~g}, 30 \mathrm{~min}, 20^{\circ} \mathrm{C}\right)$

SOLUBLE PHASE

$\beta-\mathrm{LG}$

CMP

lactose

minerals

$\downarrow$

DIAFILTRATION

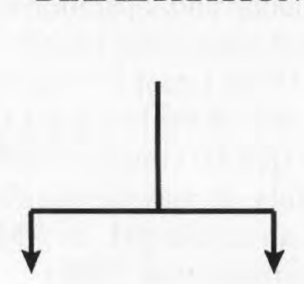

CMP $\quad \beta-L G$

lactose

minerals
PRECIPITATED PHASE

$\alpha$-LA, BSA, Ig, $\beta$-LG

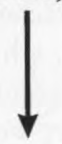

CENTRIFUGATION

2 washing steps

( $\mathrm{NaCl}, \mathrm{I}=0.1 \mathrm{~mol} \mathrm{~L}^{-1}, \mathrm{pH} 3.9$ ) 
is 0.81 and the $\alpha$-LA purity is 0.79 . Solubilisation is an additional fractionation step; BSA is the only remaining protein. If higher purity is required, different separation processes to remove BSA may be used, ie, ultrafiltration or chromatography.

\section{Performance at each step}

Figure 11 shows the schematic representation of the thermal whey protein fractionation process. Table II presents the results of this process (purity of each protein and yield at each step). Initial concentrations of the WPC are: $C_{\alpha-\mathrm{LA}}=3.6 \mathrm{~g} \mathrm{~L}^{-1}, C_{\beta-\mathrm{LG}}=$ $10.7 \mathrm{~g} \mathrm{~L}^{-1}, C_{\mathrm{BSA}}=1.0 \mathrm{~g} \mathrm{~L}^{-1}, C_{\mathrm{Ig}}=$ $3.0 \mathrm{~g} \mathrm{~L}^{-1}, C_{\mathrm{CMP}}=5.2 \mathrm{~g} \mathrm{~L}^{-1}$. Purities of WPC before and after the defatting step are equivalent. Yields of $\alpha$-LA, $\beta$-LG, BSA and Ig are low: $0.7,0.9,0.4$ and 0.5 , respectively. Protein concentrations in the defatted WPC are: $C_{\alpha-\mathrm{LA}}=2.3 \mathrm{~g} \mathrm{~L}^{-1}, C_{\beta-\mathrm{LG}}=9.25 \mathrm{~g} \mathrm{~L}^{-1}$, $C_{\mathrm{BSA}}=0.6 \mathrm{~g} \mathrm{~L}^{-1}, C_{1 \mathrm{~g}}=1.5 \mathrm{~g} \mathrm{~L}^{-1}$, $C_{\mathrm{CMP}}=4.8 \mathrm{~g} \mathrm{~L}^{-1}$.

After the precipitation step (heat treatment: 30 min, $55^{\circ} \mathrm{C}$, pH 3.9), precipitated fractions of whey proteins are: $X_{\alpha-\mathrm{LA}}=0.81$, $X_{\beta \text {-LG }}=0.02, X_{\mathrm{BSA}}=0.87, X_{\mathrm{Ig}}=0.74$. Soluble and precipitated phases are separated by centrifugation. The precipitation step permits the enrichment of the precipitated phase in $\alpha$-LA, with a purity of $\sim 0.47$, compared to 0.13 in the initial defatted WPC. The main contaminants of this ' $\alpha$-LA' fraction are Ig (24\%) and BSA (13\%). The yield of $\alpha-\mathrm{LA}$ at this step is $\sim 0.81$. $\beta-\mathrm{LG}$ in the supernatant is contaminated by CMP. The purity of $\beta$-LG is $\sim 0.62$, while that of CMP, Ig, BSA and $\alpha$-LA is $0.32,0.03,0.01$ and 0.02 , respectively.

Washing of the precipitated proteins with a $\mathrm{NaCl}$ solution $\left(\mathrm{pH} 3.9,0.1 \mathrm{~mol} \mathrm{~L}^{-1}\right.$ ) results in an increase in $\alpha$-LA purity of 0.08 , as soluble proteins (Ig and $\beta-\mathrm{LG}$ ) are removed. The yield in $\alpha$-LA at this step is 1.0 , as the protein does not solubilise in the $\mathrm{NaCl}$ solvent at $\mathrm{pH} 3.9$.
Control of the salt composition of the solvent during the solubilisation step permits two different forms of the protein to be obtained (the native form with calcium and the calcium-free form). Moreover, solubilisation is an additional selective step in the fractionation process. Using a $\mathrm{CaCl}_{2}$ solution (ionic strength $0.1 \mathrm{~mol} \mathrm{~L}^{-1}$ ) permits an increase of $23 \%$ in $\alpha$-LA purity. Ig remains insoluble and a fraction $(\alpha-\mathrm{LA}+$ BSA) is obtained directly. The yield and purity for $\alpha$-LA is $\sim 0.8$ and 0.79 , respectively. When a higher degree of solubilisation is required, a $\mathrm{NaCl}$ solution $\left(0.1 \mathrm{~mol} \mathrm{~L}^{-1}\right)$ is suitable for this purpose. In this solvent at $\mathrm{pH} 8.0$, the yield for each protein is 1.0 ; the purity of $\alpha$-LA is $\sim 0.56$ owing to the presence of Ig, BSA and $\beta-\mathrm{LG}$.

\section{Performance of the fractionation process}

Control of the salt composition of the solvent during the solubilisation step permits different fractions to be obtained. A soluble fraction $(\alpha-\mathrm{LA}+\mathrm{BSA}+\mathrm{Ig})$ is obtained, when the solubilisation solvent is a $\mathrm{NaCl}$ solution $\left(0.1 \mathrm{~mol} \mathrm{~L}^{-1}\right)$. The $\alpha$-LA yield of the fractionation process is 0.57 . Its final purity is 0.56 . The BSA yield of the fractionation process is 0.54 . Its final purity is 0.15 . The Ig yield of the fractionation process is 0.3 . The final purity of $\operatorname{Ig}$ is 0.23 .

A soluble fraction $(\alpha-\mathrm{LA}+\mathrm{BSA})$ is obtained when the solubilisation solvent is a $\mathrm{CaCl}_{2}$ solution (ionic strength $0.1 \mathrm{~mol} \mathrm{~L}^{-1}$ ). The $\alpha$-LA yield of the fractionation process is 0.46 , with a final purity of 0.79 . The BSA yield of the fractionation process is 0.43 . The final purity of BSA is 0.21 . The Ig yield of the fractionation process is 0 .

\section{CONCLUSION}

The present approach allows the optimisation of whey protein fractionation. Reduction of the free-calcium concentration by using citric acid to adjust $\mathrm{pH}$ at 3.9 permits opti- 
misation of the precipitation step. Higher precipitated fractions are obtained at a moderate protein concentration. As gelation phenomena are avoided, it results in a more efficient coupling of the precipitation and separation steps. Control of the washing solvent $(\mathrm{pH}$, salinity and ion nature) limits $\alpha$ LA loss during the washing step. Moreover, the solubilisation step permits recovery of the two forms of $\alpha$-LA (native and calcium-

Table II. Performances (purity, $P$, in each protein and yield, $\eta$, at each step) of the fractionation process.

Efficacité (pureté en chaque protéine, $\mathrm{P}$, et rendement de chaque étape) du procédé de fractionnement.

\begin{tabular}{llllll}
\hline Proteins & $\alpha-L A$ & $\beta-L G$ & $B S A$ & $I g$ & $C M P$ \\
\hline Initial concentration $\left(\mathbf{g ~ L}^{-\mathbf{1}}\right)$ & 3.6 & 10.7 & 1.0 & 3.0 & 5.2 \\
$\boldsymbol{P}_{\text {WPC }}$ & 0.15 & 0.46 & 0.04 & 0.13 & 0.21
\end{tabular}

WPC

Defatting step

$\begin{array}{llllll}\eta & 0.70 & 0.90 & 0.60 & 0.50 & 0.95 \\ \boldsymbol{P}_{\text {defatted WPC }} & 0.13 & 0.50 & 0.03 & 0.08 & 0.26\end{array}$

Precipitation step (pH 3.9, citric acid, $55^{\circ} \mathrm{C}, 30 \mathrm{~min}$ )

$\boldsymbol{X}$
0.81
0.02
0.87
0.74

\section{Centrifugation}

$\begin{array}{llllll}\boldsymbol{P}_{\text {sol }} & 0.02 & 0.62 & 0.01 & 0.03 & 0.32 \\ \boldsymbol{P}_{\text {prec }} & 0.48 & 0.10 & 0.13 & 0.24 & 0.05 \\ \eta & 0.81 & 0.05 & 0.87 & 0.71 & 0.05\end{array}$

Washing step, precipitated proteins

$\begin{array}{lcccc}\boldsymbol{P}_{\mathrm{w}, \text { WPC }} & 0.56 & 0.05 & 0.16 & 0.23 \\ \eta & 1 & 0.38 & 1 & 0.81\end{array}$

Solubilisation step ( $p H 7.5)$

$\mathrm{NaCl}$ solvent (ionic strength $0.1 \mathrm{~mol} \mathrm{~L}^{-1}$ )

$\begin{array}{ccccc}\boldsymbol{P} & 0.56 & 0.05 & 0.15 & 0.23 \\ \eta_{\mathrm{s}} & 1 & 1 & 1 & 1\end{array}$

\section{$\mathrm{CaCl}_{2}$ solvent (ionic strength $0.1 \mathrm{~mol} \mathrm{~L}^{-1}$ )}

$\begin{array}{lcccc}P & 0.79 & - & 0.21 & 0\end{array}$

BSA: bovine serum albumin.

$P_{\text {sol }}$ and $P_{\text {prec }}$ are purities in the soluble and in the precipitated phase after the precipitation step and separation by centrifugation. $P_{w, W P C}$ is the purity of the precipitated phase after washing of the pellets.

$\mathrm{P}_{\text {sol }}$ et $\mathrm{P}_{\text {prec }}$ sont les puretés de la phase soluble et de la phase précipitée après l'étape de précipitation et de séparation par centrifugation. $\mathrm{P}_{w, \text { WPC }}$ est la pureté de la phase précipitée après avoir lavé les précipités. 
free form) when the salt composition of the solvent is controlled. Furthermore, an increase in $\alpha$-LA purity of $23 \%$ is obtained in a $\mathrm{CaCl}_{2}$ solvent and a mixed $(\alpha-\mathrm{LA}+$ $\mathrm{BSA}$ ) fraction is directly obtained.

\section{ACKNOWLEDGMENTS}

This study was supported by the Centre National de la Recherche Scientifique and the Institut National de la Recherche Agronomique. Thanks are extended to A Pierre for fruitful discussions and to J Fauquant for his technical assistance.

\section{NOMENCLATURE}

$C_{\mathrm{t}}$ : initial protein concentration; $C_{\text {sup }}$ : protein concentration in the supernatant; $F$ - $\alpha$-LA $:$ weight fraction of $\alpha$-LA in the precipitated fraction after separation by centrifugation; $F_{\mathrm{W}}$ : weight fraction of the sediment; $P$ : purity of each protein (weight fraction); $X$ : precipitated fraction; $X_{\mathrm{f}}$ : precipitated fraction at steady state; $w_{\mathrm{s}}$ : weight of the initial sample; $w_{t}$ : weight of the sediment after centrifugation; $\eta$ : yield for a process step.

\section{REFERENCES}

Al-Mashikh SA, Nakai S (1987) Reduction of $\beta$-lactoglobulin content of cheese whey by polyphosphate precipitation. J Food Sci 52, 1237-1240

Amundson CH, Watanawanichakorn S, Hill CG (1982) Production of enriched protein factions of $\beta$-lactoglobulin and $\alpha$-lactalbumin from cheese whey. I Food Process Preserv 6, 55-71

Ayers JS, Petersen MJ (1985) Whey protein recovery using a range of novel ion exchangers. $N Z J$ Dairy Sci Technol 20, 129-142

Bramaud C, Aimar P, Daufin G (1995a) Thermal isoelectric precipitation of $\alpha$-lactalbumin from a whey protein concentrate: influence of protein-calcium complexation. Biotechnol Bioeng 47, 121-130

Bramaud C, Aimar P, Daufin G (1995b) Fractionation process of whey proteins: coupling a selective precipitation and membrane separation. In: Proc Euromembrane '95, 18-20 September (Bowen WR, Field RW, Howell JA, eds) Bath, UK, 292-297

Brulé G, Maubois JL, Fauquant J (1974) Étude de la teneur en éléments minéraux des produits obtenus lors de l'ultrafiltration de lait sur membrane. Lait 54 , 600-615

de Wit JN (1989) Functional properties of whey proteins. In: Developments in Dairy Chemistry, yol 4 (Fox PF, ed) Elsevier Applied Science, New York

Fauquant J, Vieco E, Brulé G, Maubois JL (1985) Clarification des lactosérums doux par agrégation thermocalcique de la matière grasse résiduelle. Lait 65 , 1-20

Gault P, Fauquant J (1992) Aptitude à la gélification thermique de la $\beta$-lactoglobuline : influence du $\mathrm{pH}$, de l'environnement ionique et de la présence des autres protéines du lactosérum. Lait 72, 491-510

Hiraoka Y, Segawa T, Kuwajima K, Sugai S, Murai N (1980) $\alpha$-Lactalbumin: a calcium metalloprotein. Biochem Biophys Res Commun 95, 1098-1104

Lin VJC, Koenig JL (1976) Raman studies of bovine serum albumin. Biopolymers 15, 203-205

Maubois JL, Pierre A, Fauquant J, Piot M (1987) Industrial fractionation of main whey proteins. Bull Int Dairy Fed 212, 154-159

Maubois JL, Léonil J (1989) Peptides à activité biologique. Lait 69, 245-269

Meisel H, Frister H, Schlimme E (1989) Biologically active peptides in milk proteins. Z Ernährungswiss 28, 267-278

Morr CV, Ha EYW (1993) Whey protein concentrates and isolates: processing and functional properties. Crit Rev Food Sci Nutr 33, 431-476

Pearce RJ (1983) Thermal separation of $\beta$-lactoglobulin and $\alpha$-lactalbumin in bovine Cheddar cheese whey, Aust J Dairy Technol 38, 144-149

Pearce RJ (1987) Fractionation of whey proteins, Aust J Dairy Technol 42, 75-78

Pearce RJ (1988) Fractionation of whey proteins, Bull Int Dairy Fed 212, 150-153

Pierre A, Fauquant J (1986) Principes pour un procédé industriel de fractionnement des protéines du lactosérum. Lait $66,405-419$

Skudder PJ (1985) Evaluation of a porous silica-based ion-exchange medium for the production of protein fraction from rennet- and acid-whey. $J$ Dairy Res 52, 167-181

Svenson A, Carlsson J (1975) The thiol group of bovine serum albumin. High reactivity at acidic $\mathrm{pH}$ as measured by the reaction with $2,2^{\prime}$-dipyridyl disulphide. Biochim Biophys Acta 400, 433-438

Tanford C, Buzzell J G, Rands D G, Swanson S A (1955) The reversible expansion of bovine serum albumin in acid solutions. J Am Chem Soc 77, 64216428

Tanimoto M, Kawasaki YYN, Shinmoto H, Dosako S, Tomizawa A, Snow Brand (1990) Process for producing (-casein glycomacropeptides. Patent EP 0393850 A2

Zadow JG (1992) Whey and Lactose Processing. Elsevier Applied Science, London 